\title{
A TRANS-CULTURAL STUDY ABOUT SUSTAINABILITY AND SUSTAINABLE FOOD
}

\author{
Handan Giraya, Abdou Gafarou Abdoulaye Bamoib; Celile Özçiçek Dölekoğllu'; Marcela Maestre- \\ Matos $^{\mathrm{d}}$, Julieth Lizcano-Prada ${ }^{\mathrm{d}}$; Federico Martínez-Carrasco ${ }^{\mathrm{e}}$ and $\underline{\text { Francisco J. Mesías }}^{\mathrm{f}}$ \\ ${ }^{a}$ Eskişehir Osmangazi University - Turkey. ${ }^{b}$ Akdeniz University Graduate School - Turkey. ${ }^{c}$ Adana \\ Alparslan Türkeş Science and Technology University Adana - Turkey. ${ }^{d}$ Universidad del Magdalena - \\ Colombia. ${ }^{e}$ Universidad de Murcia - Spain. ${ }^{f}$ Universidad de Extremadura - Spain
}

\begin{abstract}
Sustainability is a popular concept widely used by many companies in sectors as diverse as food, banking or transport. However, consumers have trouble defining and understanding it, so companies' communication efforts can be ineffective. This is even more relevant in the food production and distribution sector, since for years it has been stressed that the agricultural sector is responsible for issues such as greenhouse gas emissions, deforestation or biodiversity loss. For this reason, we considered it interesting to analyze how consumers perceive sustainability, especially in relation to food production and consumption. As the concept is difficult to define, and can be influenced by cultural aspects or lifestyles, it was decided to conduct consumer surveys in three countries with different cultural and development contexts (Spain, Turkey and Colombia), which allowed us to assess the differences in consumer perceptions, as well as to identify groups of consumers with different attitudes towards sustainability.
\end{abstract}

Key words: sustainability, food, trans-cultural

\section{Introduction and objectives}

The concept of sustainability has an increasing importance in scientific literature and is also becoming more popular for the business level. In fact, a brief literary review can help us find references to terms such as sustainable production, sustainable consumption or even sustainable loans and lighting, which provides a view of how complex defining sustainability can be and of how complex it can be for society to understand.

Within this context, the definitions of "sustainable" provided by the Spanish Dictionary (Particularly in the fields of organic production and economy, it defines something that can be maintained for a long time without exhausting the available resources or causing severe damage to the environment), that of "sustainable development" (development that satisfies the current needs without compromising the capacity of future generations to satisfy their own needs) included in the Brundtland Report (WCED, 1987) or FAO's definition of "sustainable food and agriculture" (the one in which food is nutritious and accessible for everyone, and where natural resources are managed in a way that maintains ecosystem functions to support current, as well as future human needs) (FAO, 2021) can help clarify the issue. Although there are new dimensions (such as health, ethics) added to the sustainability concept, the three dimensions within the classical sustainability approach are: environmental (prevention of environmental degradation) economic (economic growth) and social (need of growth in order to eradicate poverty).

Food consumption is one of the areas that has the greatest impact on environmental sustainability, although many consumers are not fully aware of the association existing between their food consumption and the environmental impact of food production (Eldesouky et al., 2020). On the other hand, the growing social concern for the environmental impact caused by the need to produce food in order to meet the world's demand has made consumers become increasingly interested in the way their food is produced and the production methods employed (Briggeman \& Lusk, 2011). Such trends have led to the emergence of a number of sustainability labelling projects in the food industry -i.e. Fair Trade, Rainforest Alliance- aimed at providing consumers with information on the sustainability of food. Nevertheless, the lack of familiarity of consumers with the concept of sustainability makes it difficult for them the assessment and comparison of the various products on offer (Kemp et al., 2010). This makes food companies become interested in discovering how consumers perceive sustainability so that the information provided in promotional actions or labelling can be both appreciated and capable of influencing consumer purchasing behaviour.

Hence, we decided that it might be interesting to analyze how consumers perceive sustainability, especially in relation to food production and consumption. As the concept is difficult to define and can therefore be influenced by cultural aspects or lifestyles, consumer surveys have been conducted in three countries Spain, Turkey and Colombia- with different cultural and development contexts, which has allowed us to evaluate the differences in consumers' perceptions.

\section{Methodology}

Data collection was performed by drafting a questionnaire on Google Forms (www.docs.google.com) which was distributed in October 2020-Abril 2021. This type of online tool is more and more increasingly 
used for research purposes (Viana et al., 2016) and works adequately in consume investigations due to its flexibility, low cost and the speed of collection of the information in comparison with traditional surveys.

The questionnaire included a set of questions intended to indirectly measure respondents' perceptions of sustainability. Since it was assumed that some participants might be unfamiliar with the concept of sustainability, the following definition was previously presented: "Sustainability refers to meeting society's current needs without compromising the ability of future generations to meet theirs, ensuring a balance between economic growth, environmental stewardship and social well-being. There are several related concepts, such as environmental sustainability (which emphasizes preserving biodiversity without having to give up economic and social progress), economic sustainability (which seeks the profitability of activities in a sustainable manner) and social sustainability (which seeks population cohesion and stability)".

Subsequently, 21 statements related to the purchase and consumption of food - and indirectly to economic, social or environmental aspects of sustainability - were presented and respondents were asked to indicate their agreement with them by giving a score between 1 (not at all agree) and 5 (strongly agree). The participants were contacted by email using databases created by the research team from previous studies, therefore using a convenience sampling. The final sample consisted of 341 Turkish consumers, 507 Colombian consumers and 324 Spanish consumers (53.9 \% women and $46.1 \%$ men; with most of the consumers being in the age group of 36-50 yo) who provided full and valid answers for the analysis. To analyze the data, ANOVA has been performed to assess if the ratings granted by the consumer from the three countries were significantly different.

\section{Results}

Table 1 presents the average ratings of the statements related with environmental sustainability.

Table 1. Average values for items related to environmental sustainability

\begin{tabular}{|c|c|c|c|c|c|}
\hline & Colombia & Spain & Turkey & Total & Signific. \\
\hline $\begin{array}{l}\text { Food packaging affects sustainability, due to the } \\
\text { fact that more natural resources need to be extracted } \\
\text { to produce the packaging and the pollution that } \\
\text { these generate later. That is why I try to avoid it by } \\
\text { buying more products without packaging or in bulk. }\end{array}$ & 4,19 & 4,03 & 3,67 & 3,99 & $* * *$ \\
\hline $\begin{array}{l}\text { Transportation has a great environmental impact, } \\
\text { and therefore I try to buy national or local food }\end{array}$ & 4,04 & 3,89 & 4,07 & 4,01 & $* *$ \\
\hline $\begin{array}{l}\text { Recycling food waste and its packaging at home } \\
\text { affects the environment and therefore I am } \\
\text { concerned about actively recycling at home }\end{array}$ & 3,93 & 4,16 & 4,38 & 4,12 & $* * *$ \\
\hline $\begin{array}{l}\text { I consider that the online purchase of food has a } \\
\text { greater environmental impact than the physical } \\
\text { purchase, because they have to send product only to } \\
\text { my house and it becomes more polluted }\end{array}$ & 3,51 & 3,61 & 3,91 & 3,66 & $* * *$ \\
\hline $\begin{array}{l}\text { Meat consumption has a negative impact on } \\
\text { sustainability since livestock consumes many natural } \\
\text { resources (pastures, water, feed ...) and contributes } \\
\text { to environmental deterioration (deforestation ...) }\end{array}$ & 3,63 & 3,27 & 2,83 & 3,30 & $* * *$ \\
\hline $\begin{array}{l}\text { Modern food production (using fertilizers and } \\
\text { pesticides, genetically improved varieties...) has a } \\
\text { great environmental impact and therefore I buy food } \\
\text { produced in a more natural way, such as organic }\end{array}$ & 3,79 & 3,34 & 4,09 & 3,75 & $* * *$ \\
\hline $\begin{array}{l}\text { Vegetarian diets are environmentally more } \\
\text { sustainable than a varied and balanced diet with } \\
\text { products of animal origin (meat, dairy, eggs, etc.) }\end{array}$ & 3,37 & 2,80 & 3,92 & 3,37 & $* * *$ \\
\hline $\begin{array}{l}\text { The permanent supply of out-of-season food in } \\
\text { stores requires transporting the product from areas } \\
\text { sometimes very far away, emitting large amounts of } \\
\text { greenhouse gases that affect climate change, so I try } \\
\text { to buy only seasonal foods }\end{array}$ & 3,39 & 3,66 & 4,08 & 3,67 & $* * *$ \\
\hline $\begin{array}{l}\text { The plastic bags that are generated in the purchase of } \\
\text { food have a great impact on the environment, due to } \\
\text { the resources consumed to produce them and the }\end{array}$ & 4,34 & 4,46 & 4,01 & 4,28 & $* * *$ \\
\hline
\end{tabular}


pollution they generate; that's why I always use

reusable bags when shopping for food

$*, * *, * * *$ indicate significant differences between the countries respectively at $\mathrm{p}<0.1, \mathrm{p}<0.05, \mathrm{p}<0.001$ and $\mathrm{n} . \mathrm{s}$ means not significant.

Regarding environmental sustainability, the average ratings vary among countries for all statements. However, the statements with the highest ratings are "I always use reusable shopping bags" and "recycling of waste and packaging at home" in the three countries. This allow us to stress that consumers' awareness is high regarding the negative effects of plastic packaging on environment in the three countries. While the statement "vegetarian diets are environmentally more sustainable" was granted the lowest rating in Colombia and Spain, that about "meat consumption affects sustainability negatively" was the one with the lowest rating in Turkey. Unlike Spain and Turkey, Colombia is located in the equatorial area -absent from climate seasons-, which allows a varied and permanent agri-food production throughout the year, that is why the perception of the requirement of transport for seasonal food is not very relevant. Table 2 shows the average ratings of the statements related with economic sustainability for the three countries under study.

Table 2. Average values for items related to economic sustainability

\begin{tabular}{|c|c|c|c|c|c|}
\hline & Colombia & Spain & Turkey & Total & Signific. \\
\hline $\begin{array}{l}\text { Modern food production (more intensive, with more } \\
\text { use of fertilizers and pesticides, genetically } \\
\text { improved varieties ...) guarantees the supply of food } \\
\text { at affordable prices, which is my main concern }\end{array}$ & 3,00 & 2,77 & 4,58 & 3,39 & $* * *$ \\
\hline $\begin{array}{l}\text { Online food shopping can have an effect on social } \\
\text { and economic sustainability, as it can harm local } \\
\text { businesses, employment, depopulation in my area... }\end{array}$ & 3,63 & 3,94 & 3,62 & 3,71 & $* * *$ \\
\hline $\begin{array}{l}\text { Consumption of food of animal origin (meat, dairy, } \\
\text { eggs, etc.) influences environmental and socio- } \\
\text { economic sustainability since animal husbandry can } \\
\text { contribute to conserving ecosystems and is also } \\
\text { sustainable at a socio-economic level, as a great part } \\
\text { of the population in rural areas depend on livestock }\end{array}$ & 3,74 & 3,90 & 2,33 & 3,37 & $* * *$ \\
\hline $\begin{array}{l}\text { I am concerned about the working conditions of } \\
\text { producers and workers in the food sector. This is } \\
\text { why I try to buy food in stores that guarantee } \\
\text { adequate working conditions and wages for their } \\
\text { suppliers and workers }\end{array}$ & 3,64 & 3,48 & 3,53 & 3,56 & $*$ \\
\hline $\begin{array}{l}\text { When I buy food, price is my main concern and this } \\
\text { is why I always buy the cheapest products/brands }\end{array}$ & 3,25 & 2,80 & 2,15 & 2,81 & $* * *$ \\
\hline
\end{tabular}

Table 2 shows that Spanish consumers are those most aware of the relationship between sustainability and online shopping and the effect of agricultural production on the maintenance of rural areas. It is also noteworthy how Turkish and Colombian consumers, from different points of view, show a high sensitivity to the price of food, although this does not always mean buying the cheapest products. While the consumers in Colombia and Spain think that consumption of animal products has a positive impact on socioeconomical sustainability, consumers in Turkey are worried about modern food production. These findings are in line with consumers' behaviors in environmental sustainability. Finally, Table 3 presents the average ratings granted to those statements related with social sustainability in the three countries under study.

Table 3. Average values for items related to social sustainability

\begin{tabular}{|c|c|c|c|c|c|}
\hline & Colombia & Spain & Turkey & Total & Signific. \\
\hline $\begin{array}{l}\text { Local / regional food production contributes to the } \\
\text { creation of jobs and the generation of wealth and } \\
\text { therefore I try to buy national or local food }\end{array}$ & 4,29 & 4,08 & 4,25 & 4,22 & $* * *$ \\
\hline $\begin{array}{l}\text { Food is valuable and scarce in many areas and it } \\
\text { shouldn't be wasted. That is why I try to adopt good } \\
\text { habits: buying amounts adjusted to my consumption, } \\
\text { that they do not spoil in the refrigerator, not heat } \\
\text { more food than I am going to eat, etc. }\end{array}$ & 4,33 & 4,51 & 4,17 & 4,33 & $* * *$ \\
\hline $\begin{array}{l}\text { I am concerned about the effect of diet on health and } \\
\text { try to eat a balanced diet to improve my health }\end{array}$ & 3,94 & 4,27 & 3,71 & 3,96 & $* * *$ \\
\hline $\begin{array}{l}\text { Modern food production (using fertilizers and } \\
\text { pesticides, irrigation, genetically improved varieties }\end{array}$ & 3,90 & 3,36 & 2,59 & 3,37 & $* * *$ \\
\hline
\end{tabular}


...) can have an impact on the health of consumers and therefore I buy food produced in a more natural way, such as organic

The way I buy my food (in a store or supermarket, buying online ...) can have a socio-economic impact and therefore I try to buy in nearby stores to help my neighbors and the economy in my area

3,8

The traditional / natural food production (with the use of traditional varieties, few fertilizers and pesticides ...) produces more nutritious and tasty food, so I try to buy food produced in a more natural way, such as organic

I try to reduce food waste in my home, and therefore I try to consume and not throw away the food whose best before date has passed, since I know that it does not harm my health

$*, * *, * * *$ indicate significant differences between the countries respectively at $\mathrm{p}<0.1, \mathrm{p}<0.05, \mathrm{p}<0.001$ and $\mathrm{n} . \mathrm{s}$ means not significant

Results from Table 3 show that Colombian consumers are aware that local food production contributes to job creation and therefore stand out from the other two countries when it comes to supporting the purchase of national products and in local stores, in addition to showing a trend towards organic consumption. Although consumption behaviors contribute to food waste prevention in three countries, it seems that consumer awareness of food waste in Turkey relatively lower than in the other two countries. However, it might be affected by the different presentation of "expiry date" term ("best before...", "do not eat after..." "eat preferably before...") and which may confuse consumers. Indeed, the study found that consumers in all countries pay attention to food waste and local food. However, Colombians and Turkish participants did not find it important to consume expired foods and not throw them away.

\section{Conclusions}

In spite of such opportunities for agrifood producers deriving from the higher demand of sustainable food, consumers are scarcely familiar with the concept, which makes it harder for them to evaluate and compare the various products on offer and can cause confusion. It is, therefore, necessary to educate and inform consumers about the concept of sustainability so that the information provided by the producers can be of value for consumers and impact their purchasing behaviour. Despite the different cultural and economic backgrounds, consumers in the three countries under study consider all actors in the food supply chains in their countries and their profitability. In addition to that and although its average level varies among countries, it was found that the first motivation is not the price for consumers regarding sustainability.

In this sense, public institutions must implement policies and instruments that, on the one hand, foster the production and marketing of sustainable food as a way to contribute to mitigate environmental deterioration and climate change and, on the other hand, may influence consumers to become aware and value food produced in this way. For this purpose, it is essential for them to understand the implications of sustainability and not only in its narrow environmental side, but in its entire social and economic extent.

\section{Bibliography}

Briggeman, B. C., \& Lusk, J. L. (2011). Preferences for fairness and equity in the food system. European Review of Agricultural Economics, 38(1), 1-29. https://doi.org/10.1093/erae/jbq033

Eldesouky, A., Mesias, F. J., \& Escribano, M. (2020). Perception of Spanish consumers towards environmentally friendly labelling in food. International Journal of Consumer Studies, 44(1), 64 76. https://doi.org/10.1111/ijcs.12546

Kemp, K., Insch, A., Holdsworth, D. K., \& Knight, J. G. (2010). Food miles: Do UK consumers actually care? Food Policy, 35(6), 504-513. https://doi.org/10.1016/j.foodpol.2010.05.011

FAO (2021). Sustainable Food and Agriculture. http://www.fao.org/sustainability/background/en/

Viana, M. M., Silva, V. L. S., Deliza, R., \& Trindade, M. A. (2016). The use of an online completion test to reveal important attributes in consumer choice: An empirical study on frozen burgers. Food Quality and Preference, 52, 255-261. https://doi.org/10.1016/j.foodqual.2015.11.016

World Commission on Environment and Development. (1987). Our Common Future. Oxford University Press. 